\title{
“ALL THAT PERTAINS TO MEDICINE": PROTOMEDICI AND PROTOMEDICATI IN EARLY MODERN ITALY
}

\author{
by
}

\section{DAVID GENTILCORE *}

In 1621 the vice-protomedico of the Papal States was arrested while inspecting an apothecary's shop and charged with committing financial irregularities in the course of his duties. Giacomo Giacobelli had received his doctorate in 1598 and, in addition to being physician at St John Lateran in Rome, was serving for the third time as vice-protomedico. As Giacobelli told the judges of the Apostolic Chamber, his authority as vice-protomedico in the Papal States outside Rome was analogous to the protomedico's power within the city.

That is, to punish, whether civilly or criminally, any crime whatever concerning medicine, and discover and bring to an end every civil, criminal and mixed case which concerns the said profession. And furthermore, to examine and license surgeons and apothecaries, and confirm the licences already obtained by barbers and surgeons, or withdraw them ...

Two apothecaries had denounced Giacobelli. One, Pietro Buonaugurio, an apothecary with forty years' experience in Tivoli, declared that Giacobelli had fined him twenty-five scudi even though he had no faulty goods in his shop. When Buonaugurio had protested, Giacobelli reduced the fine, first to fifteen scudi and then to ten. When Buonaugurio refused to pay even this, Giacobelli sent in the sbirri, ${ }^{2}$ who removed Buonaugurio's bronze mortar as surety. On his own initiative, Buonaugurio took the offending drugs to Rome. Here they were examined by three members of the College of Apothecaries and found to be of good quality. ${ }^{3}$

Other medical practitioners testified against Giacobelli. A barber named Andrea Lucchese had refused to appear before Giacobelli and pay the licence fee, claiming he had never needed a licence before. Giacobelli had the sbirri clear his shop, at which point Lucchese paid the fee of six giuli. Bartolomeo Giovannini, also a barber, at first refused

* David Gentilcore, PhD, Churchill College, Cambridge CB3 0DS.

I should like to thank Alvar Martínez Vidal, Ottavia Niccoli and Alessandro Pastore for their assistance. My gratitude also to the staffs of the Archivi di Stato of Naples, Rome, Bologna, and Siena, in particular Giuliana Adorni (Rome) and Tiziana di Zio (Bologna). Finally, my thanks to the Wellcome Trust for a travel grant to carry out this research.

\footnotetext{
1 Archivio di Stato, Rome (hereinafter A.S.R.), Università, busta 1, 'Processo contra D. Iacobum Iacobellum V. Protho.cum, 1620', fol. 90v. All translations are my own, except where noted otherwise.

${ }^{2}$ Armed guards employed as a rudimentary police force. For the low repute in which the sbirri were held and their role in enforcing justice, see Steven Hughes, 'Fear and loathing in Bologna and Rome: the Papal police in perspective', J. soc. Hist., 1987, 21: 97-116.

3 'Contra Iacobum Iacobellum', op. cit., note 1 above, fols. 26 and 150v-2.
} 


\section{David Gentilcore}

to pay for a licence, on the grounds that he was already licensed but had lost the certificate. ${ }^{4}$ A widow named Sarra Vitale was imprisoned and fined twenty-five scudi "for teaching a young shoemaker called Giacomo Lombardo a remedy of drinking a certain wood water [i.e., lignum vitae] to free himself from certain frigid pains he had". In addition, she stated, Giacobelli sought to have her pay ten scudi for a "licence to medicate", plus the expenses Giacobelli had incurred during his stay, but "I did not want to give anything, since I am not a healer" (medichessa) ${ }^{5}$ Finally, two sisters, both midwives in Tivoli, testified against the vice-protomedico. They declared that they had been practising for many years without a licence before Giacobelli came along. Their justification was that "no one in Tivoli has ever heard that to be a midwife a licence was needed". Giacobelli had forced each woman to pay eight giuli for her licence. ${ }^{6}$

The court of the Apostolic Chamber, the state's massive financial organ, was concerned to ascertain how Giacobelli charged licence fees and enforced fines. Giacobelli asserted throughout the trial that there had been no wrong-doing. Rather ruefully, he described how much of his time had been spent collecting the money owed to the protomedicato and the College of Physicians, often paid in instalments which licensees did not always respect. The taking of sureties was a necessary precaution. He denied ever taking payments which he did not note in his register. As for demanding payment for the expenses of room, board and stabling, this was part of his due recompense as vice-protomedico during tours of inspection, though he had waived it in the case of the woman Vitale. ${ }^{7}$ Presumably, the court found Giacobelli guilty of fraud, because twenty years later, when it felt sure of support, the protomedicato launched a lawsuit against the Apostolic Chamber for its proceedings against Giacobelli. ${ }^{8}$

The trial against Giacobelli is a fitting way to begin this introductory study of the protomedici and protomedicati of early modern Italy. Whether Giacobelli was innocent or guilty, it is obvious that an office created to oversee the medical profession and the practice of medicine had to contend with much else as part of the power structures in society. The trial hints at the financial preoccupations which were so much a feature of office-holding in early modern Europe. It also suggests the tensions caused by conflicting and overlapping jurisdictions and authority that pitted one magistracy against another, as well as the multiplicity of interests involved in bringing offenders to law. As we shall see, this is true whether the protomedicato in question was a creation of the monarch or lay within the local medical college. The activities of such bodies were conditioned by the "political culture and the institutional and legal framework of the larger society" in which they operated. Early modern Italy was a myriad of different states, so this essay will begin with a brief survey of the origins of the various Italian protomedicati. As the office is generally associated with Spain and its empire, it will be useful to compare its Italian

\footnotetext{
4 Ibid., fol. 155.

${ }^{5}$ Ibid., fols. 66 and 157-9.

6 Ibid., fols. 165-6.

${ }^{7}$ Ibid., fols. 94v., 101 and 106-7v.

${ }^{8}$ Cf. Fausto Garofalo, Quattro secoli di vita del Protomedicato e del Collegio dei Medici di Roma (Regesto dei documenti dal 1471 al 1870), Rome, Pubblicazioni dell'Istituto di storia della medicina dell'Università di Roma, 1950, p. 38.

${ }^{9}$ As Matthew Ramsey has noted in the context of late ancien régime France, in 'The repression of unauthorized medical practice in eighteenth-century France', Eighteenth-Century Life, 1982, 7: 118-35, on p. 119.
} 


\section{Protomedici and protomedicati in early modern Italy}

versions. In part II we shall turn to the functions and activities of the protomedicati, before concluding with an examination of their jurisdictional limitations and their characteristics as offices in the early modern state. All the protomedicati will be included in this survey, although the limitations posed by surviving archival records necessitates a geographical emphasis on those of Rome, Bologna, and Siena, and a chronological emphasis on the seventeenth and early eighteenth centuries.

\section{I}

Although health legislation and mechanisms for supervising the day-to-day practice of medicine in the Italian states certainly existed during the Middle Ages, they gained force in the sixteenth century with the establishment of specific structures like the protomedicati. These took three forms: collegial, royal (or Spanish), and municipal. The magistracies in both Rome and Siena were of the first type, having grown out of the medical colleges of these cities. The Rome College of Physicians is said to have been founded in the twelfth century, as a guild, though the earliest surviving reference to it is the confirmation of the college's statutes by papal bull in 1471. In Rome the protomedico gradually took over the authority of the college's prior. Likewise in Siena, the first protomedico, to judge by surviving records, held office from 1562, while the post of prior became largely ceremonial. ${ }^{10}$ The protomedicato of Bologna was a similar outgrowth of that city's medical college, which established the tribunal in 1517. Its origins, however, lay in the disciplinary norms contained in the 1378 Statutes of the College of Medicine and Arts. These granted the college jurisdiction over disputes between doctors and patients and over the inspection of apothecaries' shops and the charging of fines. It was also responsible for the licensing of "charlatans"; for this reason, the three people appointed to carry out these tasks were called the "assumpti contra empyricos". ${ }^{11}$ In 1553 Bologna and its immediate territory was declared exempt from the jurisdiction of the Roman protomedicato. But, although this gave the Bolognese protomedicato formal independence, a recognition of that city's importance in medicine, Rome continued to claim a certain superiority. Beginning with a papal brief of 1576, Rome asserted that all physicians wishing to practise in Rome and the Papal States had to be examined before the Roman protomedico and several members of the Rome College of Physicians, regardless of where they had taken their doctorates. This enraged the Bolognese authorities; the dispute lasted until 1727, when Pope Benedict XIII-who had himself studied at Bologna-recognized the privileges of Bologna University. ${ }^{12}$

The story in Naples and Sicily is quite different. Here, due to a relatively strong central administration, royal ordinances regulated the medical profession from early on. ${ }^{13}$ Both

${ }^{10}$ A. Garosi, 'I protomedici del collegio di Siena dal 1562 al 1808', Bullettino senese di storia patria, 1938, 9: 173-81.

"' Edoardo Rosa, 'L'Assunteria di sanità nella difesa della salute pubblica a Bologna durante il XVIII secolo', in Famiglie senatorie e istituzioni cittadine a Bologna nel Settecento, Bologna, Istituto per la storia di Bologna, 1980, pp. 179-234, on pp. 182-3.

12 Cf. Antonio Brighetti, 'Documenti inediti sulla controversia fra il Collegio dei Medici di Bologna e di Roma circa l'esercizio della professione', Atti e memorie dell'Accademia di storia dell'arte sanitaria, 1965, 44: pp. 67-73.

${ }^{13}$ Carlo Cipolla, Public health and the medical profession in the Renaissance, Cambridge University Press, 1976, pp. 5-6, and Richard Palmer, 'Physicians and the state in post-medieval Italy', in A. W. Russell (ed.), The town and state physician in Europe from the Middle Ages to the Enlightenment, Wolfenbüttel, Herzog August Bibliothek, 1981, especially pp. 57-9. 


\section{David Gentilcore}

kingdoms owe the first appointment of protomedici to Aragonese kings. Initially, the protomedico's role as "first among physicians" 14 was an extension of his status as the personal physician of the king. In 1397 King Martin II of Sicily appointed the first protomedico, Ruggero de Camma, with authority over the whole island. ${ }^{15}$ It was de Camma who compiled the statutes of the apothecaries in $1407^{16}$ and was present at the king's deathbed two years later, among the king's followers during his campaign in Sardinia. ${ }^{17}$ The 'Capitula et ordinaciones' of the Sicilian protomedicato were compiled in 1429 by the protomedico Antonio d'Alessandro and approved by King Alfonso the Magnanimous, according to Giovanni Filippo Ingrassia, who revised them. ${ }^{18}$ Alfonso also appointed a protomedico for the Kingdom of Naples when he became king there in 1444, apparently following what was established local practice. ${ }^{19}$ In fact, his immediate predecessor, Queen Giovanna II, had set up a medical college in the city of Naples, naming her personal physician, Salvatore Calenda of Salerno, as its prior. ${ }^{20}$ More formal recognition of the office came in an imperial "privilege" issued by Charles V in 1530 to the then protomedico of Naples Narciso Verdugno, who was having difficulty enforcing his powers. He was given the authority "to examine, recognize, and castigate all non-graduate physicians, surgeons, apothecaries, grocers, alchemists, barbers, enchanters, healers, midwives, and any other persons subject or attached to the said offices". ${ }^{21}$

Both protomedicati were closely linked to the Spanish viceroyal administration. It was not unusual for well-connected physicians to circulate amongst the various medical offices in the two kingdoms, to the annoyance of local physicians. Domenico Bottoni, for instance, was appointed Sicilian protomedico by the viceroy, the Marquis of Villafranca, an office which he continued to hold under the two succeeding viceroys. In 1688 he was nominated protomedico general of Naples by the viceroy there, the Count of Santo

\footnotetext{
14 Antonio Santorelli, Il protomedico napolitano, ovvero dell'autorità di esso. Dialogo raccolto da un discepolo ... e data in luce dal signor Fabio Cava, Naples, Roberto Mollo, 1652, p. 3. For studies based on Santorelli's treatise, cf. Pasquale Franco, 'Il protomedico napoletano', Pagine di storia della medicina, 1965, 9: 15-32, and Luigi de Rosa, 'The "protomedicato" in southern Italy, XVI-XIX centuries', Annales cisalpines d'histoire sociale, 1973, 4: 103-17.

${ }^{15}$ Giuseppe Pitrè, Medici, chirurgi, barbieri e speziali antichi in Sicilia, secoli XIII-XVIII, Rome, Biblioteca delle tradizioni popolari siciliane, 1942, p. 162.

${ }^{16}$ Archivio di Stato, Palermo, Cancelleria, reprinted in Pitrè, op. cit., note 15 above, pp. 392-9.

17 Alberto Boscolo, La politica italiana di Martino il Vecchio re d'A ragona, Padua, CEDAM, 1962, p. 150. As part of the Aragonese realms, Sardinia eventually acquired its own protomedicato. Cf. Ignazio Lai, 'Farmacopea e farmacoterapia nella Sardegna seicentesca. Spigolature d'archivio', Studi sardi, 1987, 17: 315-47, on pp. 315-16.

${ }^{18}$ Giovanni Filippo Ingrassia, Constitutiones, capitula, iurisdictiones, ac pandectae regiiprotomedicatus officii, Palermo, Nicolai Bua, 1657, introduction. The book was first published in 1564; the 1657 edition was revised by the then protomedico Paolo Pizzuto. Ingrassia (1510-80) taught anatomy in Naples before becoming Sicilian protomedico general. As the result of his experiences during the Palermo plague of 1575, he wrote the Informatione del pestifero et contagioso morbo, il quale affligge et have afflitto questa città di Palermo, Palermo, G. M. Mayda, 1576.

${ }^{19}$ Alan Ryder, The kingdom of Naples under Alfonso the Magnanimous. The making of a modern state, Oxford, Clarendon Press, 1976, p. 79.

${ }^{20}$ Miguel Muñoz, Recopilación de las leyes, pragmáticas reales, decretos y acuerdos del Real Proto-medicato hecha por encargo y dirección del mismo Real Tribunai, Valencia, 1751, reprint Valencia, Librerías París, 1991 , p. 37.

21 Santorelli, op. cit., note 14 above, pp. 25-6.
} 
Stefano. For the next four years he was forced to use a pseudonym, since statute required that the office be filled by a local physician. ${ }^{22}$ Bottoni was not the only Sicilian to be offered the post. Several decades earlier, the then viceroy of Naples, Juan Alonso Enriquez de Cabrera, had offered the post to the Messinese Marco Antonio Alaimo. Before becoming Neapolitan viceroy, De Cabrera had been viceroy in Sicily and no doubt came across Alaimo there. Alaimo had gained renown during the Palermo plague of 1624-5, publishing a treatise on the subject. ${ }^{23}$ But Alaimo refused the appointment, preferring to remain in Sicily, thereby avoiding a dispute with Neapolitan physicians. In 1634 he was appointed consultor protomedico in Palermo. ${ }^{24}$

Despite these close links with the Spanish administration, the royal protomedicati in Italy never achieved the authority of their Spanish counterpart. In Spain, much more so than in Italy, the Tribunal del Protomedicato developed into a vast and powerful bureaucracy, branching out into all areas of the kingdom and overseas possessions. It appointed medical personnel to hospitals and the armed forces, regulated the publication of books on medical subjects, and directed efforts against plague and contagion. ${ }^{25}$ However, just as the Iberian tribunal faced the overlapping jurisdiction of other state offices and medical corporations, so the tension between royal prerogative and the medical colleges surfaced in the other Italian protomedicati of Milan, Parma, and Savoy. When the Duchy of Milan became a Spanish possession in 1535 the post of protofisico regio was established as an imperial appointment. He was normally chosen from amongst the ranks of the Milanese medical college (composed entirely of noblemen); such was Milan's most famous protofisico, Ludovico Settala, appointed to the office in 1628 by Philip IV. ${ }^{26}$ This proximity did not, however, guarantee tranquil relations between the two. Spanish influence was also behind the founding of the protomedicato in the Duchy of ParmaPiacenza more than two hundred years later, after the duchy was assigned to the Spanish Philip of Bourbon at the Treaty of Aix-la-Chapelle in 1748. The institution of the protomedicato by decree in 1749 deprived the "college of doctors of arts and medicine" of

\footnotetext{
${ }^{22}$ Santorelli does not mention this regulation, though he may take it for granted. Bottoni was Neapolitan protomedico until 1692, when he returned to Messina for health reasons. In 1695 he was made corresponding member to the Royal Society in London, to supply information about the 1693 Messina earthquake. His son, Federico (c.1670-c.1745), served throughout the Spanish world: in addition to offices in Naples and Sicily, he was court physician first in Madrid and then in Lima. Cf. Alvar Martínez Vidal, El nuevo sol de la medicina en la Ciudad de los Reyes: Federico Bottoni y la Evidencia de la circulación de la sangre (Lima, 1723), Saragossa, Aragón y América, 1992.

${ }^{2.3}$ Marco Antonio Alaimo, Discorso . . . intorno alla preservatione del morbo contagioso e mortale che regna al presente in Palermo, Palermo, Angelo Orlandi, 1625.

${ }^{24}$ Roberto Zapperi, 'Marco Antonio Alaimo', Dizionario biografico degli italiani, Rome, 1960, vol. 1, pp. 561-2.

25 Juan Riera and Juan Granda-Juesas, introduction to Pascual Iborra, Historia del Protomedicato en España (1477-1822), Universidad de Valladolid, 1987, p. 10; Luis Granjel, Historia general de la medicina española, vol. 2, Medicina española renacentista, Universidad de Salamanca, 1980, pp. 76-7; for Spanish America, cf. John Lanning, The royal protomedicato. The regulation of the medical profession in the Spanish empire, ed. J. Tepaske, Durham, N.C., Duke University Press, 1985.

${ }^{26}$ Settala (1552-1633) served as a deputato during the Milan plague of 1576 and wrote a successful treatise on the subject (De peste et pestiferis affectibus, 1622). Cf. Pietro Capparoni, Profili bio-bibliografici di medici $e$ naturalisti celebri italiani dal sec. XV al sec. XVIII, Rome, Istituto nazionale medico farmacologico, 1928, vol. 2, pp. 131-2; Silvia Rota Ghibaudi, Ricerche su Ludovico Settala, Florence, Sansoni, 1959, pp. 18 and 41.
} 


\section{David Gentilcore}

Piacenza University of the authority to examine physicians and surgeons and license apothecaries and non-graduate practitioners. ${ }^{27}$

A final example of the close relationship between protomedico and ruler is in the Duchy of Savoy. Here we have a mixing of the first two types of protomedicato. In 1565 Duke Emmanuele Filiberto gave his "protomedico and counsellor", Marc'Antonio Capra, authority to inspect apothecaries' shops and proceed against them for any malpractice. In 1568 this authority was extended over all other medical practitioners. However, the establishment of a protomedicato did not eliminate the medical college in Turin. Later edicts refer to the examination of doctors by the protomedico, the prior of the college and college members, though the protomedico could also hold the post of college prior. ${ }^{28}$

A third distinct type of protomedicato existed in Italy, and can be designated the municipal. Here the protomedico was a local physician elected for a short period by the town or city council. In many cases the office was a survival from the days of communal autonomy, as at Gubbio or the papal enclave of Benevento, not far from Naples. The protomedico here was elected by city counsellors, and had the authority to inspect apothecaries' shops, establish fines for malpractice, and issue licences to non-graduate practitioners in the city of Benevento and its immediate vicinity. Although he was independent of the Roman protomedico, serious offences amongst the medical profession had to be referred to the papal legate. ${ }^{29}$

Protomedici in different states had various terms of office. In Sicily, the office remained a royal appointment, independent of the island's medical colleges. It was a prestigious position and the Sicilian protomedico general's entry into the city of Palermo was an occasion for pomp. In 1581 Francesco Bisso was accompanied by city nobles, senators and knights. ${ }^{30}$ Likewise, in the Kingdom of Naples, the protomedico received an annual salary of one thousand ducats from the state. Originally a life appointment, in 1573 it was changed by the viceroy Cardinal Granuela to a one year term. ${ }^{31}$ In Rome, however, the office continued to be an integral part of the medical college. Here, the protomedico general was elected annually each December from amongst the ranks of the college to be its head. He had to have been a member of the college for at least three years, be at least forty years of age, and reside in the city. His first task was to publish an edict outlining the rules and regulations for the practice of medicine, and to choose two vice-protomedici and various provincial protomedici to carry out the actual tours of inspection. Although not a prerequisite for office, the protomedico general was often the pope's archiater as well, as was the anatomist Giovanni Maria Lancisi in $1711 .^{32}$ Similarly, in Siena, the protomedico

\footnotetext{
${ }^{27}$ Costituzioni del Regio-Ducale Protomedicato de' nostri stati di Parma, Piacenza e Guastalla, Parma, 1749, cited in Emilio Nasalli-Rocca, 'Il Collegio dei dottori di arti e medicina di Piacenza', Atti e memorie dell'Accademia di storia dell'arte sanitaria, 1951, 17: 17-26, on p. 26.

${ }^{28}$ Giovanni Battista Borelli, Editti antichi e nuovi de' sovrani principi della Real Casa di Savoia, Turin, 1681, edicts of $1565,1568,1604$, and 1646, pp. 965-89.

29 'Statuta civitatis Beneventi' (1588), Museo del Sannio, Benevento, Fondo civico, ms. 5362, I, ch. 15, 'De protomedico'; reprinted in appendix to Gaetana Intorcia, Civitas beneventana. Genesi ed evoluzione delle istituzioni cittadine nei secoli XIII-XVI, Benevento, Auxiliatrix, 1981, pp. 185-6.

${ }^{30}$ Pitrè, op. cit., note 15 above, p. 161.

${ }^{31}$ Santorelli, op. cit., note 14 above, pp. 98 and 115.

32 Statuta Collegii DD. Almae Urbis Medicorum, Rome, 1676, A.S.R., Biblioteca: Statuti, 322. In fact between 1530 and 1745 , of the 102 protomedici general listed, 20 were also papal archiaters. This can be confusing, as the term protomedico sometimes indicates a ruler's personal physician, regardless of his other roles.
} 


\title{
Protomedici and protomedicati in early modern Italy
}

was chosen every March from those who had been college members for at least eight years. ${ }^{33}$ The situation in Bologna was somewhere between the two poles of state versus college control. Although protomedici were elected from among college members, their salary was paid by the city Senate. This overlap resulted in increasing tension as the government tried to assert its authority over health matters. So, for example, in 1575 when, without consulting the college, the governor appointed the naturalist Ulisse Aldrovandi protomedico, to prepare the city's Antidotario, or official pharmacopoeia, the college expelled Aldrovandi (with the support of the city's apothecaries, it must be said). Recourse by Aldrovandi to the city's governor led eventually to the intervention of Pope Gregory XIII two years later, who ordered the college to reinstate him. In fact, there developed a hierarchy in state-medical relations in Bologna, as elsewhere. The medical profession as a body was favoured over the chaotic mass of charlatans and empirics, the college over physicians in general, and, finally, the protomedicato over the college. ${ }^{34}$

\section{II}

Despite their differences, the activities and responsibilities of the protomedici and their deputies were remarkably similar throughout the peninsula. There was the grinding reality of tours of inspection. These "visitations", as they were called, were the raison d'être of the protomedicati. In their reports, the inspecting vice-protomedici emphasized the ritual and formal tone of the inspections, designed, no doubt, to impress, if not intimidate, those who were subject to inspection and the payment of licence fees and fines.

\begin{abstract}
We, the aforementioned protomedici of the bounteous city of Bologna for the second trimester of the year 1677, eager carefully to undertake our office, devised for the public good, according to custom ... did assemble in the church of S. Giacomo Maggiore, summoned by note, his excellency D. Raimondo Abello vice-protomedico, D. Agostino Stanzani steward of the [Company of] Apothecaries, D. Giovanni Battista Cavazzi secretary of the College [of Physicians], D. Giulio Gallici porter and I, Ippolito Poggioli protomedico, and, having heard mass, we ascended by carriage and travelled on our route to Castel Budrio, directed towards the inspection of apothecaries' shops ... 35
\end{abstract}

Roads could be bad, especially in the mountains. A Roman vice-protomedico for 1711 , Giacomo Marchetti, wrote to the protomedico from a very small town near Imola, remarking how he had arrived there over a "very bad mountain road, slightly worse than the pass between Umbria and Romagna in the mountains of the Apennine Alps of Florence". ${ }^{36}$ The mere official title of the Turinese protomedico suggests difficulties: "protomedico general both on this side and beyond the mountains". Need isolated villages be visited personally? When vice-protomedico Marchetti was informed of a surgeon near Lugnano who was administering internal medicines in violation of his licence, he had an

${ }^{33}$ Constitutiones collegij senensis philosophiae et medicinae doctorum, Siena, Matthaeum Florimum, 1612, Archivio dello Stato, Siena, Archivio dello Studio (hereinafter A.S.S., Studio), b. 44. Cf. A. Garosi, 'Medici, speziali, cerusici e medicastri nei libri del protomedicato senese', Bullettino senense di storia patria, 1935, 6: $1-27$, on p. 2.

${ }^{34}$ Cf. Giuseppe Olmi, 'Farmacopea antica e medicina moderna. La disputa sulla teriaca nel Cinquecento bolognese', Physis, 1977, 19: 197-245, on p. 237.

${ }^{35}$ Archivio di Stato, Bologna (hereinafter A.S.B.), Assunteria di Studio, b. 87, 7 June 1677.

${ }^{36}$ A.S.R., Università, b. 62, fol. 169. 


\section{David Gentilcore}

injunction served by the local physician rather than go there himself, "since there is no apothecary's shop in the place and it is rather inconvenient to any itinerary". ${ }^{37}$ Rain or bandits could make travel worse. Plans had to be changed. When heavy rains blocked the roads into Romagna, one vice-protomedico went into part of Umbria and conducted inspections there instead. ${ }^{38}$ Another was kept away from certain towns on his route "by fear of bandits, since there was no safe road". 39 Indeed, in the Kingdom of Naples members of the inspection team were permitted to bear arms and were accompanied by an armed guard of a handful of soldiers. ${ }^{40}$

The adventures met with on the road were those experienced by most travellers. In 1735, the Sienese protomedico and his following, whilst on their way from Castel del Piano to Radicofano, encountered terrible mountain roads, blocked by "rocks, thickets, gorges, and horrible things", as well as a fierce storm of rain, wind, and fog. As they were approaching the village of Abbadia for the night they were soaked by a sudden downpour, and then found that the only inn could offer them neither supper nor a bed. They were taken in by a local official. On the following morning, as they were about to leave, it began to pour again, and so they found refuge in the local monastery. As guests, they were served a special vegetable soup that evening, which contained a local delicacy: mushrooms known as olientole. However, "all of us who ate [the soup] were so sick that we thought we were going to die that night, and we did nothing but go to vomit or defecate". They finally managed to get to Radicofani the next day, "after having suffered further great cold, wind and rain", but without additional mishap. ${ }^{41}$

Upon arrival in a town the Roman protomedico or his deputy was to call upon the governor or other local official. "You will kiss his hands"-advised a 1620 'Instruttione' - “on behalf of the Protomedico General and all of the College, explaining that you have been sent for the public good and benefit of that place, so that delinquents are punished and the people well served in all that pertains to medicine". ${ }^{2}$ He was to ask the governor's consent to carry out the inspections of apothecaries' shops, inviting him to participate if he so wished. It was important to make a good impression with the local governors, as they could make life difficult for inspecting protomedici. ${ }^{43}$ And with town after town to visit, it was important that things should go as smoothly as possible.

Inspecting apothecaries' shops was the protomedico's most important activity, to judge by the amount of space devoted to it in both the regulations and the reports. ${ }^{44}$ The "visitation" was to take the apothecary by surprise. In the words of the Neapolitan protomedico Antonio Santorelli, it was to be like death: "the apothecary knows it will come, but he does not know the day or time". ${ }^{45}$ This was to prevent him from disposing of

\footnotetext{
${ }^{37}$ Ibid., fol. 1435.

${ }^{38}$ Allegedly with the permission of the vice-protomedico responsible for that area. A.S.R., Università, b. 2, XI.

${ }^{39}$ A.S.R., Università, b. 2, v, fol. $3 \mathrm{v}$.

${ }^{40}$ Lorenzo Giustiniani, Nuova collezione delle prammatiche del Regno di Napoli, Naples, Stamperia Simoniana, 1805 , vol. 12, p. 223.

41 A.S.S., Studio, b. 62 , fol. $64 \mathrm{v}$.

42 'Instruttione e Capitoli da osservarsi dal S.r Iacomo Iacobelli da Colle Vecchio Viceprotomedico fuora di Roma per lo Stato Ecc.co del anno 1620', A.S.R., Università, b. 1, fol. 42.

${ }^{43}$ Cf. A.S.R., Università, b. 62, fols. 169-70.

44 The registers of the Bolognese protomedicato give a good idea of the tribunal's day-to-day activities. 'Registri degli atti del protomedicato', A.S.B., Archivi dello Studio, bb. 318-27 (hereinafter A.S.B., Studio).

${ }^{45}$ Santorelli, op. cit., note 14 above, p. 69.
} 
deficient or inferior medicines, or borrowing good ones from another apothecary (crimes that took place nevertheless). In addition to the inspection's formalistic and somewhat ominous nature, it could turn into a real social event, further adding to the ritual. In an unusually detailed description, a physician named Antisari, delegated to inspect an apothecary's shop in the town of Vitorchiano, related the event to the Roman protomedico:

[The apothecary] asked for time to put his shop in order. And this was agreed to, on condition that neither he nor his shop boy could leave the shop and would have to put everything in order in my presence and that of the aformentioned apothecary [Cammilli, accompanying Antisari on his inspection], and that no one would enter the shop during the time set aside for this preparation. And so it went. The potestà, the syndic of the place, who is the chief magistrate, and two of their peasants, his [the apothecary's] companions, participated in the inspection. There was the archpriest, a doctor, and a quantity of people. The inspection followed, enquiring item by item and diligently examining all the things demanded in the List... and nothing deficient was found ... but everything was well made and in abundance. ${ }^{46}$

The presence of so many people at the inspections was meant to guarantee they were carried out properly. But this was not always easy. Apothecaries were often reluctant to have their shops inspected and pay the visitation fee. They frequently justified this by pleading poverty. Normally apothecaries were not paid immediately, "as are butchers or bakers", but sometimes after many years, if at all. ${ }^{47}$ The Bolognese apothecary Pastarino (a nickname) lamented the need to hire a "collector", whose task it was to go to people's homes, often repeatedly, to demand payment, "like some pauper begging for alms" ${ }^{48}$ In small towns and villages the result could be penury. Petitions to be exempted from the payment of inspection duties because of poverty - the latter due to "the high cost of medicines which the poor cannot afford to pay for", as one apothecary complained ${ }^{49}$ may therefore have been quite genuine. Where, as in the Papal States, the viceprotomedici depended on the apothecaries for their room, board and stabling expenses while in a town on inspection, they had to ensure that they got what was due to them without upsetting their hosts. In 1618, for example, the apothecary of Monte Marciano complained that the vice-protomedico had come to his village "with three horses and stayed here for two days, entirely at my expense, because of some bad weather, even though he could have left in the evening ... I am a poor fellow, with the burden of a family, and, for the small amount of trade I do, this was a blow to me". ${ }^{50}$ Vice-

${ }^{46}$ A.S.R., Università, b. 62, fol. 1579.

${ }^{47}$ Santorelli, op. cit., note 14 above, p. 108.

${ }^{48}$ Ragionamento del Pastarino sopra l'Arte della Speciaria. Alli Mag.ci et Illustri Senatori di Bologna. Accioché si pigliano cura di questo utilissimo essercitio, Bologna, 1575, cited in Piero Camporesi, La miniera del mondo. Artieri, inventori, impostori, Milan, Il Saggiatore, 1990, p. 250.

${ }^{49}$ Archivio di Stato, Naples (hereinafter A.S.N.), Dipendenze della Sommaria: Protomedicato, series II, fascio 35 , "cautele".

${ }^{50}$ A.S.R., Università, b. 1, fol. 239. The Bolognese protomedici had to pay for their own expenses, which were then reimbursed by the Assunteria di studio. This meant one less source of tension during inspections. Petitions by protomedici to the Assunteria suggest that this payment (it amounted to 50 lire) was not always prompt in coming, nor was it always sufficient to cover expenses. A.S.B., Assunteria di studio, b. 87, 28 May 1586 and 16 May 1638. 


\section{David Gentilcore}

protomedico Papi thought he had got the balance right. While admitting to his superiors in Rome that his inspections had been somewhat summary, he boasted "of having carried out the inspection as a man of honour, clean-handed, with all modesty and respect, without provoking and burdening the apothecaries, with whose wretchedness I sympathized, and I even reduced part of what they owed me for expenses". ${ }^{51}$ Yet all the goodwill in the world did not prevent an unwilling apothecary from locking his shutters, and going into hiding ${ }^{52}$ or even seeking sanctuary in the parish church when accused of illegal trading. ${ }^{53}$ Apothecaries were not defenceless, however, having their own colleges to look after their interests. This they did, bringing them into frequent dispute with medical colleges and protomedicati up and down the peninsula.

It must be said that the protomedici were relatively lenient when it came to fines, although their enforcement may seem somewhat arbitrary. Their bark was always worse than their bite. A 1939 study of the Sienese protomedicato ridiculed the contrast between the "wordy and high-sounding intransigence" of the edicts and the clemency shown to actual offenders, especially when they pleaded poverty. A mattress-maker who specialized in treating leg sores and ringworm, was pardoned because he was "very poor" and "the father of three small children". 54 This may strike the present-day reader rather differently: as a pragmatic, if not enlightened, approach. In any case, it was typical of ancien régime law enforcement. This often came down to levels of bargaining, the final punishment being a compromise between the harshness of the edicts and the pretentions of the accused. ${ }^{55}$ In 1711 the apothecary Cesare Floridi complained to the protomedicato in Rome that he had been fined too much for not having a certificate on his vase of theriac. The inspection itself had been a farce, according to Floridi: "he came [to my shop] with a young apothecary who knew about as much of the profession as his stable boy (begging Your Illustrious Lordship's pardon), and when he examined the medicaments he did nothing but shrug his shoulders". Floridi was fined ten scudi, but, he commented, the protomedico's deputy was clearly not adverse to a little bribery, in the form of wine and chickens, which Floridi refused to give. He concluded his complaint by noting that another apothecary was fined only six scudi, which included the visitation fee, for a similar offence. In the end, Floridi was fined five scudi. ${ }^{56}$

The protomedici's difficulties did not merely concern apothecaries. In Forlì, viceprotomedico Marchetti lamented,

you cannot get anyone at short notice, whether physicians, midwives or surgeons. And, although the bailiff is sent for everyone, he comes back saying the doctors are on call, he could not find the surgeons and, of the midwives, some come with their licences, others are either not at home or he did not find them, they being who knows where. You wait a few more hours before recommencing the trip; but it serves no purpose...

51 A.S.R., Università, b. 2, XI.

52 A.S.B., Studio, b. 197, fol. 156.

${ }^{53}$ A.S.R., Università, b. 62, fol. 1439.

${ }^{54}$ Garosi, op. cit., note 33 above, p. 15 . Garosi's article contains no references, but the trial can be found in A.S.S, Studio, b. 58 , fols. $239-46$.

${ }^{55}$ For an example of how this process of negotiation worked to preserve individual interests, cf. John Brackett, Criminal justice and crime in late Renaissance Florence, 1537-1609, Cambridge University Press, 1992, p. 74.

${ }^{56}$ A.S.R., Università, b. 62, fols. 1469 and 1481 . 


\section{Protomedici and protomedicati in early modern Italy}

This was clearly ruining Marchetti's plans to "get on with the Romagna and, having finished this, enter the Marches". 57 Examining barber-surgeons and midwives, issuing licences, and collecting fees was never a straightforward or popular business. Merely carrying out one's duty was bound to cause resentment, as the not always legitimate accusations against Giacomo Giacobelli suggest (see above, pp. 121-2). Licence renewals were particularly difficult. The vice-protomedico for 1700 , the physician Pietrangelo Papi, cynically noted that "it is the long-established practice in most towns that upon the arrival of the vice-protomedico all the licensees who must carry out renewals hide themselves, and the contumacious flee, until the vice-protomedico and the notary (who comes with me and is responsible for the said tasks) have left". ${ }^{58}$

Barber-surgeons were generally grouped into three different levels of skill, and licensed accordingly. First-degree barbers, according to a list compiled by the Bolognese protomedicato in 1682, were licensed only "to draw blood from the arm and foot, to apply leeches and cupping glasses". Second-degree barbers were permitted "to draw blood from every part of the body and to treat simple wounds". Finally, third-degree barbers "can practise every surgical act on the exterior part of the body, draw blood, place leeches, treat ulcers, simple wounds, bone fractures and luxations". 59 In addition to the relevant licence fees, there were very heavy fines for exceeding the limits of one's licence as granted by the protomedico. This was true for the rest of the Papal States as well. The vice-protomedico could only issue one-year licences for "light surgery" (in casibus levibus), the granting of perpetual licences for full surgery being up to the protomedico general.

Similar restrictions not to exceed the bounds of their profession also applied to midwives. The 'Instruttione' issued to the Roman vice-protomedico in 1620 stated that women were not to be licensed to treat the sick but only to practise midwifery. ${ }^{60}$ The first of the edicts issued by the Roman protomedici general upon taking office to mention midwifery was that of $1628 .^{61}$ The Neapolitan protomedico Santorelli, writing in 1652 , commented that midwives need not be examined on what the pregnant woman should do before and after the birth; she need only know what to do during the birth. ${ }^{62}$ In Bologna the first edict obliging midwives to present themselves and undergo examination and approval by the protomedici dates from $1674 .{ }^{63}$ This was repeated three years later, advising every midwife "to present a testimonial from her curate, de vita et moribus [on her life and morals], into the hands of the prior or the protomedici", to be approved by them. ${ }^{64}$ These edicts were repeated at regular intervals, but that of 1746 is particularly harsh. It suggests that many midwives outside Bologna still practised without a licence, "fooling themselves

57 A.S.R., Università, b. 62, fols. 170 and 173.

${ }^{58}$ A.S.R., Università, b. 2, XI.

59 'Catalogo de' barbieri e comari ... ordinato l'anno 1682', A.S.B., Studio, b. 235. Cf. Gianna Pomata, 'Barbieri e comari' in Cultura popolare nell'Emilia Romagna. Medicina, erbe e magia, Milan, Cassa di Risparmio di Emilia Romagna, 1981, pp. 162-83.

60 'Instruttione ... ', A.S.R., Università, b. 1, fol. 44.

${ }^{61}$ A.S.R., Università, b. 24, bando 22. Formal instruction for Roman midwives began in 1782 (A.S.R., Università, b. 59, XL).

${ }^{62}$ Santorelli, op. cit., note 14 above, p. 56.

${ }^{63}$ It is mentioned in A.S.B., Studio, b. 214 , no. 6. Siena had to wait until 1713 for a similar edict, though a number of midwives had been licensed by the protomedico in 1686 , following a complaint from the Balia. A.S.S., Studio, b. 51, fol. 267, and ibid., b. 49, fol. 271.

64 'Editto per li speciali, barbieri, comari et altri', 1677, A.S.B., Studio, b. 233. 


\section{David Gentilcore}

into thinking that they can do so". ${ }^{65}$ This particular edict would seem to have come in the wake of a warrant against an unlicensed midwife in the village of Castagnolo, described in the registers of the protomedicato. ${ }^{66}$ The situation was less the result of any intent to deceive than due to the traditional way of selecting a community midwife. By the mid-eighteenth century it was becoming a conflict between two different levels of society. ${ }^{67}$ This can be inferred from the naturally hostile comments of one Roman vice-protomedico that "the pregnant women and the people create midwives at their own whim, who then openly pass themselves off as such, without any recognition or experience at all, to the great harm of mothers and infants". ${ }^{68}$ Generally, midwives were chosen by the community because of acquired experience, skills frequently passed from mother to daughter, but it was the fact that this was done without official sanction that the vice-protomedico objected to. The records do contain testimonials from parish priests or physicians, commending the ability of a local midwife and requesting her licensing by the protomedico, though the normal practice was most likely to await the annual inspections. ${ }^{69}$ In Siena, there was a tacit acknowledgement that, in the absence of taught courses, the only way a woman could gain the knowledge of midwifery necessary in order to be approved and licensed was through previous, unlicensed, experience. ${ }^{70}$

Another important aspect of the activity of the protomedicati regarded the licensing of charlatans. The protomedici were not out to extinguish the presence of charlatans in their states, but to regulate their circulation and the goods they peddled. The Neapolitan protomedico Santorelli explained that charlatans must be tolerated and licensed because, in the case of syphilis, "many victims would go to them who, because of shame, would not dare go to a doctor or surgeon". ${ }^{71}$ This detached attitude was not shared by all protomedici, primarily because so many charlatans seemed to escape licensing. The licensing of charlatans had begun with the medical colleges, like the "assumpti contra empyricos" within the college at Bologna. Sixteenth-century edicts were usually directed against the actitivities of unlicensed healers in general, but as early as 1572 the pretore protomedico of Palermo issued an edict specifically against mountebanks and charlatans who distributed internal remedies without a licence. ${ }^{72}$ Twenty-two years later, an edict issued by the cardinal legate of Bologna declared all previous licences void and obliged all charlatans to submit their drugs to the college for examination. To be approved, the drug in question would have to receive favourable votes from two-thirds of the college members present. ${ }^{73}$ The Roman vice-protomedico of 1620 was instructed to use "excellent diligence

65 'Notificazione ...', 1746, A.S.B., Studio, b. 233.

${ }^{66}$ A.S.B., Studio, b. 322, fols. $38 \mathrm{v}$ and $46 \mathrm{r}$. From this year the examination and approval of midwives becomes a regular feature of the registers, with an average of two or three midwives licensed every year. A noteworthy exception is 1772, when twenty-seven midwives were approved in two sittings, held at the Archiginnasio (A.S.B., Studio, b. 327).

${ }^{67}$ Cf. Claudia Pancino, Il bambino e l'acqua sporca. Storia dell'assistenza al parto dalle mammane alle ostetriche (secoli XVI-XIX), Milan, Franco Angeli, 1984, p. 52.

${ }^{68}$ A.S.R., Università, b. 62, fol. 1648.

${ }^{69}$ A.S.R., Università, b. 62, fols. 1659 and 1679.

${ }^{70}$ A.S.S., Studio, b. 63 , fol. 79v. The Sienese protomedicato was the most flexible-indeed lenient-when it came to the licensing of medical practitioners of all kinds.

71 Santorelli, op. cit., note 14 above, p. 48.

72 Cited in Pitrè, op. cit., note 15 above, p. 293.

${ }^{73}$ A.S.B., Studio, b. 233. 


\section{Protomedici and protomedicati in early modern Italy}

in locating the medicasters, maimers [stroppiatori], charlatans or others who treat without legitimate licence", charging them for the room, board and stabling expenses necessitated by examinations. He was supplied with a list of such charlatans and other unlicensed healers, whom he was to keep an eye out for. ${ }^{74}$

Of the Roman edicts that of 1672 was the most detailed and severe. The Roman protomedico general Antonio Piacenti, noting that most charlatans were "outsiders and from other countries", warned that they must all submit their wares for examination and approval to the protomedico in Rome (and outside Rome, to his vice-protomedici or the physicians of the place).

They must obtain the licence, authority and privilege to prepare, sell and distribute any electuary (as against poisons), oils, ointments, plasters, balms, preserves, quintessences, waters, decoctions and other things of whatever kind and quality, and ... they must not make any preparation of them if the ingredients they want to dispense and use in the work have not been personally examined and approved first . . . and a reasonable price assigned.

In order "to attract the public to buy [their goods]", they were not "to expound upon or discuss anything concerning medicine in any way, but only what they have been permitted to dispense". Those with patents to sell electuaries against poison, or ointments for wounds were not "to swallow poisons of any sort, nor have themselves bitten by snakes or other poisonous animals, nor to cut or burn their own flesh...without our permission . . . so that people are not deceived". They were not to administer the remedies themselves, even free of charge, since this was the province of surgeons. The patent could not be transferred to another person, even a relative, without authorization. ${ }^{75}$ Even at this, its most restrictive, the activity of the protomedicati was not aimed at eliminating the "scourge of quackery", but at gaining some control, however minimal, over it. The presence of the "without permission" clause in so many of the regulations meant that permission could be granted, and frequently was. In fact, each of the regulations regarding charlatans which make up this edict is reflected in the surviving licensing and criminal records of the various protomedicati. These contain detailed applications from charlatans for patents to sell their drugs, some approved, others rejected. Charlatans were also tried for selling goods without a licence or selling goods other than those for which they were licensed. Descendants of the original licensee would also petition for the patent to be passed on to them as heirs.

Because a number of protomedici also wrote treatises on plague, it is worthwhile asking at this juncture what relationship the protomedicati had with the peninsula's health boards. In Palermo, for example, the consultor protomedico compiled the statutes of that city's Magistrato di sanità, which was reorganized in 1575 to consist of the city's pretore, the captain of justice, the protomedico and nineteen members of the aristocracy. ${ }^{76}$ More often, however, the health boards were in the hands of non-medical administrators. ${ }^{77}$

74 'Instruttione . . ', A.S.R., Università, b. 1, fols. 44r.-v.

75 'Bando generale del protomedico', 1672, A.S.R., Università, b. 25.

${ }^{76}$ Statuti del Magistrato della sanità della felice città di Palermo, compilati da Agostino Gervasi consultore protomedico per comandamento del senato palermitano, Palermo, 1728, cited in, Calogero Valenti, 'Due episodi di peste in Sicilia (1526 e 1624)', Archivio storico siciliano, 1984, 10: 5-88, on p. 25.

${ }^{77}$ Cipolla, op. cit., note 13 above, pp. 21-3. 
Protomedici, given their status, might serve on them or furnish advice. Nothing in the registers of the Bolognese protomedicato, however, suggests any official involvement with the city's health board. ${ }^{78}$ The contribution of protomedici to the health boards was of a more ad hoc nature. Such was the role of the Roman protomedico Benedetto Rita in supplying the Congregazione della sanità with a consultation on the treatment of plague during the epidemic of $1656 .^{79}$ The actual administrative and bureaucratic arrangements were left to the boards. These arrangements, or lack of them, could be the source of dispute. In 1629 the aging protofisico of Milan critized the laxity of the Tribunale di sanità in recognizing the presence of plague in the city and surrounding towns. ${ }^{80}$ But there was not much he could do. Nor is there much evidence that the Italian protomedicati communicated with one another, at least on an institutional level. Aside from the lengthy dispute over jurisdiction with Rome and an edict from the Milanese protofisicato ${ }^{81}$ the only communications received by the Bolognese protomedicato from other offices concerned false doctorates. $^{82}$

\section{III}

The various protomedicati differed from one another in the extent of their jurisdictions. Yet to some degree they all competed, or at least overlapped, with trade corporations and other organs of the state. Although the state apparatus grew in size during the early modern period, this did not mean that it replaced or even weakened other centres of power. Local elite groups and traditional institutions maintained their importance in European states. ${ }^{83}$ Even the most powerful protomedicato, that of Spain, had to share its authority with local medical corporations, especially in cities outside Castile. ${ }^{84}$ Moreover, the Supreme Council of the Inquisition also assumed the right to license charlatans, inspect apothecary shops and examine and approve foreign physicians in certain circumstances. ${ }^{85}$

As far as Italy is concerned, let us begin by considering geographical limitations. The royal protomedico of Sicily had jurisdiction over the entire island, but nonetheless had to contend with the presence of municipal protomedici in Palermo, Catania, Messina, and Modica. The essentially honorific post of pretore protomedico is mentioned in the

\footnotetext{
${ }^{78}$ The only noteworthy shift in their activities as a result of plague was the very high number of apothecaries examined and licensed in 1631, in the wake of the 1630 epidemic. A.S.B., Studio, b. 213, no. 6. No records of the Roman protomedicato survive for 1656-57, the year of the epidemic there.

${ }_{79}$ Biblioteca Corsiniana, Rome, ms. 34.D.17, fol. 11 v., cited in Pietro Savio, 'Ricerche sulla peste di Roma degli anni 1656-1657', Archivio della società romana di storia patria, 1974, 95: 113-42, on p. 123.

${ }^{80}$ Fausto Nicolini, 'La peste del 1629-1632', in Storia di Milano, Milan, Fondazione Treccani, 1957, vol. 10, pp. 509-10.

${ }_{81}$ A.S.B., Studio, b. 233.

82 Thus, the Milan protofisicato advised that it had caught a certain Giovanni Palavicino of Sondrio with a false doctorate from Bologna University, dated 7 February 1742 and signed "with fake cardinal and archdeacon, fake vicar, fake notary and seals all fake", A.S.B., Studio, b. 214 , no. 2.

${ }^{83}$ Tommaso Astarita, The continuity of feudal power. The Carracciolo di Brienza in Spanish Naples, Cambridge University Press, 1992, p. 202.

${ }^{84}$ Granjel, op. cit., note 25 above, p. 78; cf. José Mariá López Piñero, 'The medical profession in 16th century Spain', in Russell, op. cit., note 13 above, p. 85.

${ }^{85}$ J. L. Valverde and F. Sánchez L. Vinuesa, 'Controversias jurisdiccionales del protomedicato castellano', Asclepio, 1979, 30-31: 403-23. The case of a Neapolitan physician in Cadiz, found without licence from the protomedicato, went before the Inquisition, who exiled him, despite petitions from the protomedicato. Cf. Guadalupe Albi Romero, El protomedicato en la España ilustrada (Catálogo de documentos del Archivo General de Simancas), Universidad de Valladolid, 1982, items 226-226b, pp. 101-2.
} 


\section{Protomedici and protomedicati in early modern Italy}

Palermo city statutes of $1478 .^{86}$ The real work of examinations, inspections, and licensing was done by his consultor protomedico, who might, like Francesco Bisso, go on to become protomedico of Sicily. The protomedico of the Kingdom of Naples had supposedly universal authority, reflected in his title "regio e generale protomedico". But there were the notable exceptions of Salerno and Benevento. ${ }^{87}$ Salerno was the only city in the kingdom to have a collegial entity, the Medical College, completely autonomous from its Neapolitan counterpart (until 1810 and the reforms of Joachim Murat). Although Salerno's medical school lost its preeminence during the early modern period, its college continued to be an important tool in the city's local power structure. ${ }^{88}$ Benevento, as a papal enclave, was also independent. Indeed, the protomedico of Benevento was even independent from the Roman protomedico, though he did not escape the ultimate authority of the papal legate. In other ways the extent of the territory under the Roman protomedico general was less that his title of "generalis protomedicus totius status ecclesiastici" implied. We have already mentioned Bologna, which became part of the Papal States in 1506 and jealously sought to retain remnants of local autonomy. In addition, the towns of Castro and Ronciglione, Ravenna, Rimini, and Urbino were similar exceptions, as were places like Macerata, Fermo, and Perugia, with their medical colleges. There were even exceptions to the exceptions. Whilst the former Duchy of Urbino, since 1631 under the control of the papal legate, retained its own protomedicato, the latter was itself subject to the claims of Gubbio, whose "first physician" claimed local authority there. ${ }^{89}$

There were also personal exemptions. Unlike the Spanish tribunal, the Italian protomedicati-even those created on the Spanish model-did not have jurisdiction over university educated physicians and surgeons. At the most, newly-graduated or foreign physicians would have to undergo an additional examination by the protomedico before being able to practise. The protomedico of Naples was typical in having precedence over all other physicians in the kingdom, but he could proceed against them only if they were suspected of preparing medicines. ${ }^{90}$ In medical matters the Sicilian protomedico's power was supposed to supersede that of the viceroy. In his edition of the Constitutiones the protomedico Paolo Pizzuto even gives the example of a licence granted to a distiller by the viceroy, the Marquis de los Velez, which because of Pizzuto's firm opposition the viceroy was forced to withdraw and seek the protomedico's forgiveness. Pizzuto was clearly staking a claim here; but because the appointment was made by the king, upon the viceroy's recommendation, this cannot have been a regular occurrence. ${ }^{91}$ It suggests, moreover, that the viceroy regularly issued patents to non-graduate practitioners.

In Bologna, the protomedico had to contend with similar powers possessed by the cardinal legate. Though the relationship seems to have been generally harmonious, their powers overlapped when it came to the issuing of patents to charlatans and mountebanks.

${ }^{86}$ L. Siciliano (ed.), Consuetudini di Palermo, Palermo, 1894, p. 451, cited in Pitrè, op. cit., note 15 above, p. 110.

${ }^{87}$ Santorelli, op. cit., note 14 above, pp. 8-11.

88 Salvatore De Renzi, Storia della medicina italiana, Naples, 1845-48, vol. 3, pp. 142-3.

89 'Breve dei medici e speziali', Archivio di Stato, Gubbio, Fondo comunale, fol. 73, cited in Pier Luigi Menichetti, Medici e speziali in Gubbio, Città di Castello, Rubini e Petruzzi, 1974, p. 79.

${ }^{90}$ Santorelli, op. cit., note 14 above, p. 34.

91 Ingrassia, op. cit., note 18 above, p. 40-2. 


\section{David Gentilcore}

Technically, the examination and approval of their remedies fell under the jurisdiction of the protomedicato, but the cardinal legate had authority over all outsiders wishing to trade within Bologna. The licence fees charged represented a steady source of income for the legate's office. In one year from October 1595 to October 1596 fifteen licences were issued, at four lire each, valid for one month. ${ }^{92}$ In one case, the protomedicato specifically requested the cardinal legate not to issue a licence and safe-conduct to a maker and seller of an electuary against poison. ${ }^{93}$ Yet the combined licensing activities of both the protomedico and the cardinal legate did not manage to snare all of the mountebanks circulating in the city. The following case, from the warrants (mandati) issued by the legate, is but the tip of the iceberg. Two men, imprisoned for "selling oils, ointments and distilled waters in the square without a licence", were released because of their poverty and ordered not to sell anything without a licence from the legate. ${ }^{94}$

Another perennial thorn in the side of the Bolognese protomedici was the issuing of privilegi in camera, chamber or court diplomas granted by noblemen for personal service in their households. These were seen as a threat to the authority of the protomedicato, for they could only be invalidated, and physicians so licensed prohibited from practising, in the area under its jurisdiction: Bologna and immediate vicinity. Despite such prohibitions, Bolognese physicians continued to administer summary examinations as requested, prior to countersigning these diplomas. ${ }^{95}$ The fine for physicians practising in Bologna with only the privilegio di camera was 100 gold scudi in 1594; but such was the menace, that it was raised to 500 scudi in an edict forty years later. ${ }^{96}$

The protomedici were generally powerless against apothecary shops belonging to religious orders. "If one tries to punish them", as one Roman protomedico put it in 1619, "one encounters nothing but considerable distress, troubles, interference, and vexations". 97 This was the norm throughout Italy, until the reforms of the late eighteenth-century limited the autonomy of the religious orders. ${ }^{98}$ Further jurisdictional limitations varied from state to state. Barbers were generally approved and licensed by the protomedici, but in the city of Naples-though not outside it-barbers were subject only to their own guild, the Quattro dell'Arte. ${ }^{99}$ In Milan, the separation of the protofisicato and the city's medical college resulted in occasional conflict between the two over jurisdiction. The protofisico also had to come to terms with the demands of the duchy's five colleges of apothecaries regarding fees. In Cremona, for example, a compromise had to be reached in 1718 , whereby apothecaries were required to obtain a double licence from both the local

\footnotetext{
${ }^{92}$ A.S.B., Studio, b. 117. Charlatans were also obliged to pay an annual tribute of forty-four bolognini to the Company of Apothecaries, according to the Riforma de' statuti dell'Onoranda Compagnia de' Speziali, A.S.B., Assunteria delle Arti speciali, b. 22, cited in Camporesi, op. cit., note 48 above, p. 274.

${ }^{93}$ A.S.B., Studio, b. 320, 10 Oct. 1680.

${ }^{94}$ A.S.B., Legato: Expeditiones, b. 65, 9 May 1570, fol. 39.

${ }^{95}$ One case concerned a "physician" in the service of the Prince of Armstatt, made all the worse because he was only a surgeon, cf. 'Processo contro a Sebastiano Poggi davanti al Magistrato de' Sig.ri Protomedici', 1725, A.S.B., Studio, 213, no. 21.

96 A.S.B., Studio, 233.

97 'Discorso dell'inconvenienti che nascono nella medicina, fatto da Lorenzo Garzonio Protomedico Generale, 1619', A.S.R., Università, 61, fol. 780.

${ }^{98}$ In Siena, for instance, the apothecaries' shops of the religious orders were first inspected in 1776, by order of Grand-Duke Leopold, A.S.S., Studio, b. 63, fols. 112-14.

${ }^{99}$ Santorelli, op. cit., note 14 above, pp. 51-2.
} 


\section{Protomedici and protomedicati in early modern Italy}

college of apothecaries and the protofisico. ${ }^{100}$ There were sometimes restrictions on the right of protomedici to inspect and proceed against wholesale grocers, who traded in many of the same goods as apothecaries and frequently supplied them. While the Rome protomedico could inspect grocers and fine them for misdemeanours, ${ }^{101}$ his Turinese counterpart could proceed against them, in concert with the city's vicario, only by appealing to the Senate. ${ }^{102}$ In Naples, the protomedico Prospero Bove assumed control over the grocers in 1581 after a spate of deaths resulted from poisons they had sold. Henceforth they were to keep records and be inspected like the apothecaries. ${ }^{103}$ This immediately incurred the wrath of the grocers and the authority was withdrawn by the viceroy and the Collateral Council (the kingdom's highest political-administrative organ) in 1604. It was argued that poisons like arsenic and verdigris were necessary for the work of artisans and, in any case, could be just as easily obtained from other sources. In addition, it was unnecessary to inspect the grocers' shops since the goods they sold were inspected upon their manufacture or importation, and what medical goods were bought by apothecaries would undergo further inspection by the protomedico. ${ }^{104}$ But the problem did not go away. For the tax farmers awarded the contract to collect the dues of the protomedicato, the "right of inspection" of those grocers' shops dealing in compound medicines was an additional source of income which they sought to enforce. ${ }^{105}$

The collegial and municipal protomedicati were subject to various organs of the state, though they clearly had more authority and room to manoeuvre, not to say prestige, than the limited magistracies of other trade corporations. ${ }^{106}$ In Rome, the Apostolic Chamber could intervene when petitioned to do so, as the vice-protomedico Giacomo Giacobelli found out to his dismay in 1621. It is clear that the protomedicato and the College of Physicians would have preferred to deal with the matter themselves and regarded the proceedings of the Apostolic Chamber against Giacobelli as an intrusion. These impediments to its authority formed the subject of a complaint made by the protomedico general, Lorenzo Garzonio, two years earlier. He noted that the College of Physicians and the protomedicato were founded so that "intelligent and leading people" would oversee the medical profession, checking the audacity of those who dared to treat the sick despite "knowing no more than a stone about medicine". However, they were obstructed in conducting criminal and civil trials against these transgressors, so that "the affairs of medicine are no longer conducted with suitable authority, decorum, and esteem". In addition to preventing Garzonio from proceeding against Giacobelli, the Apostolic Chamber had obstructed Garzonio's actions against certain grocers in the city. They had been illegally selling inferior theriac and mithridatum, both college monopolies. Garzonio wanted to take legal action to defend the college's authority, but the general lack of

\footnotetext{
${ }^{100}$ Anita Malamani, 'L'organizzazione sanitaria nella Lombardia austriaca', in A. De Madalena, E. Rotelli, G. Barbarisi (eds), Economia, istituzioni, cultura in Lombardia nell'età di Maria Teresa, vol. 3, Istituzioni e società, Bologna, il Mulino, 1982, pp. 995-6.

101 Statuta collegii, op. cit., note 32 above, p. 21.

102 Borelli, op. cit., note 28 above, edict of 1604 , p. 970.

${ }^{103}$ Giustiniani, op. cit., note 40 above, pp. 202-6.

${ }^{104}$ Santorelli, op. cit., note 14 above, pp. 13-24.

${ }^{105}$ Carlo Antonio Broggia, Trattato de' tributi, delle monete, e del governo politico della sanità, Naples, $\mathrm{P}$. Palombo, 1743, pp. 292-3.

${ }^{106}$ For a discussion of the guilds in seventeenth-century Rome, cf. Laurie Nussdorfer, Civic politics in the Rome of Urban VIII, Princeton University Press, 1992, pp. 128-35.
} 


\section{David Gentilcore}

revenues prevented this. The same legal step should have been taken, Garzonio remarked, when the city governor issued him with an injunction preventing him from proceeding against the seller of a remedy made with castor seeds, which had caused the deaths of several people. The diminution of the college's authority resulted in other "disorders". Physicians formed forbidden alliances with apothecaries, but when the protomedico went to proceed against them he found himself issued with an injunction. These abuses extended to surgeons, midwives, and charlatans, who could no longer be disciplined for exceeding the limits of their professions. Midwives treated the sick and then pleaded poverty when the protomedico sought to punish them. Harking back to a golden age, Garzonio concluded: "If the college had the authority which it had before, it would not admit such people to so noble a profession, nor would it permit the affairs of medicine to be dealt with by anyone other than physicians and apothecaries". ${ }^{107}$

In the Papal States, as elsewhere in early modern Europe, conflicts of jurisdiction were common. Each state organism had its own tribunal to investigate cases affecting its interests and employees. This meant that one person could find himself on trial before different tribunals for the same charge. ${ }^{108}$ Edicts regarding the protomedici of Turin prohibited other magistrates from interfering in their activities, but it is difficult to say how effective these were. ${ }^{109}$ The authority of the ecclesiastical tribunals, inquisitorial and episcopal, also overlapped with that of the protomedicati regarding popular healing rituals. In Naples, according to the protomedico Antonio Santorelli, those who treated wounds with "meaningless words" were subject to the protomedicato, "but those who heal with words and characters must be recognized by ecclesiastics, who are to judge whether to permit such a form of healing or prohibit it as superstitious and containing some tacit pact with the devil". 110 Jurisdiction in such matters was never clear. Women performing healing rituals could find themselves denounced before either of the two tribunals, regardless of the actual nature of their cures (never easy to determine in any case, given the mixture of sacred and profane). This was true throughout Italy. Certainly there is little to distinguish the cures for "haemorrhoids, shingles, ringworm, leg sores" administered by Anna Maria Belavia, charged before the Bolognese protomedicato in 1698 for healing without a licence, from those denounced before the Inquisition in nearby Modena. ${ }^{111}$ It was a case of which court was notified of such healers first, since a woman using magical remedies to treat the sick was also most likely doing so without any sort of licence. Most accusations before the protomedicato were made by physicians and surgeons, perhaps

\footnotetext{
${ }^{107}$ Garzonio, op. cit., note 97 above, fols. 776-80.

${ }^{108}$ Hanns Gross, Rome in the age of the Enlightenment. The post-Tridentine syndrome and the ancien régime, Cambridge University Press, 1990, pp. 217-21.

${ }^{109}$ For instance, the 1646 edict issued by Duchess Christiana, in Borelli, op. cit., note 28 above, p. 989.

${ }^{110}$ Santorelli, op. cit., note 14 above, p. 33. In Spain, the royal pragmatic of 1477 gave the protomedicato the authority to make certain no one made use of "spells, conjurations and incantations", especially when they were "administered medically", though the Supreme Council of the Inquisition (established 1483) was to be the prime mover in this area. Cf. Granjel, op. cit., note 25 above, p. 147; Jaime Contreras and Gustav Henningsen, 'Forty-four thousand cases of the Spanish Inquisition (1540-1700): analysis of a historical data bank', in G. Henningsen and J. Tedeschi (eds), The Inquisition in early modern Europe. Studies on sources and methods, Dekalb, Northern Illinois University Press, 1986, pp. 100-29.

${ }^{\prime 11}$ A.S.B., Studio, 321, 27 Nov. 1698. For Modena, see Mary O'Neil, 'Magical healing, love magic and the Inquisition in late sixteenth-century Modena', in S. Haliczer (ed.), Inquisition and society in early modern Europe, London, Croom Helm, 1987, pp. 88-114.
} 


\section{Protomedici and protomedicati in early modern Italy}

fearing illicit competition, and because they were most familiar with the tribunal's functions. Those outside the medical profession might denounce the same women before the Inquisition or the episcopal courts, made wary-by preachers, confessors, and missioners - of the "superstitious" or diabolical element present in such cures. ${ }^{112}$

The nature of the protomedicato as an office closely linked to the state is reflected in other ways. This was particularly true of those based on the Spanish model, as in Naples. Whereas in Rome the various fees and fines paid to the protomedicato funded college salaries and costs, in Naples the income went to the state treasury. Here, the protomedicato was one of many arrendamenti or tax farms (from the Spanish arrendar, to contract). This was a system by which the tax farmer, or arrendatore, would offer an anticipated sum of money at public auction based on the annual revenues due to that office. The arrendatore, usually by means of a system of sub-contracts, then undertook the collection of the taxes or duties. ${ }^{113}$ The arrendamento of the protomedicato was set up in 1610 , for which the first contractor bid 8,330 ducats, keeping for himself the emoluments derived from the granting of licences and diplomas, the inspection of apothecaries' shops, and the payment of fines. ${ }^{114}$ Earnings remained relatively low during the seventeenth century, but in the eighteenth it became a lucrative source of income for the crown. ${ }^{115}$

The arrendatore or his deputy was part of the "team" which went about the kingdom inspecting apothecaries' shops, collecting licence fees, examining non-graduate practitioners, and settling medical disputes. Accompanying him were the protomedico, or his deputy, the proto-apothecary, and three soldiers. ${ }^{16}$ While relations between physicians and apothecaries generally seem to have been good, as early as 1743 there were complaints that farming out the collection of duties seriously harmed the practice of medicine. Because the arrendatore's motivation was purely financial, it was alleged that diplomas and licences were issued without the required examination, resulting in the "mushrooming" of practitioners. Inspections of apothecaries' shops were carried out only after notice had been given, allowing apothecaries to dispose of inferior goods and borrow good quality ones, so that, especially in the provinces, the inspection became a mere formality. Seeking to intervene and remedy these ills, the protomedico "finds the way blocked by the pestiferous cause of the tax contract". ${ }^{117}$ These comments were made by a grocer-cum-fiscal reformer with his own axe to grind, but by 1780 even the president of the Royal Academy of Sciences, the influential Prince of Francavilla, was also advocating

\footnotetext{
112 On the role of popular healing, see David Gentilcore, From bishop to witch. The system of the sacred in early modern Terra d'Otranto, Manchester University Press, 1992, pp. 128-61.

${ }^{113}$ Luigi de Rosa, Studi sugli arrendamenti del Regno di Napoli. Aspetti della distribuzione della ricchezza mobiliare nel Mezzogiorno continentale (1649-1806), Naples, Arte Tipografica, 1958.

114 Lidia Castaldo Manfredonia, Gli arrendamenti, fonti documentarie conservate presso l'Archivio di Stato di Napoli, Naples, Arte Tipografica, 1986, vol. 1, p. 162.

115 Annual earnings were under 5,000 ducats for most of the $1600 \mathrm{~s}$, rising to around 9,000 during the years of Austrian occupation (1707-34), and running between 15,000 and 19,300 during the late 1780s. (A.S.N., Dip. Somm.: Protomedicato, series I, fasci 280 I, 280 Il, 281, 282.) But, to keep things in perspective, the gabelle on playing cards brought in more money, whilst the tobacco arrendamento earned the state over ten times as much (cf. Antonio Calabria, The cost of empire. The finances of the Kingdom of Naples in the time of the Spanish rule, Cambridge University Press, 1991, pp. 134-41; Antonio Di Vittorio, Gli Austriaci e il Regno di Napoli, 1707-1734, vol. 1, Le finanze pubbliche, Naples, Giannini, 1969, p. 207.)

116 Fabio Cava, 'Instruttioni che s'hanno da osservare dal Protomedico, Protospeziale e Affittatore', in Santorelli, op. cit., note 14 above, pp. 85-95.

${ }^{117}$ Broggia, op. cit., note 105 above, pp. 289-91.
} 


\section{David Gentilcore}

reform. The Prince recommended that the arrendatore be stripped of "the authority to dispense licences to practise medicine, whether in physic or in surgery or obstetrics". Apothecaries' shops should be inspected directly by physicians of the crown or the protomedico, "without the involvement of the arrendatore, whose task is to represent the treasury, allowing him to claim only the jus visitationis [inspection fee], which is six carlini". ${ }^{118}$ Indeed, the records of the arrendamento of the protomedicato-all that survives with reference to the tribunal's activities-contain numerous complaints from apothecaries against the arrendatori. But the arrendamento was then at its most profitable, and nothing was done.

Needless to say, the collection of these emoluments could lead to abuses whether it was carried out directly by tax collectors or not. These are present in all three types. As early as 1484-86, in an early example of the literature of roguery, Teseo Pini included protomedici in his list of swindlers, charlatans and false vagabonds. Under the guise of overseeing the practice of medicine, they really acquired the position in order to fill their own pockets, Pini commented. They were in fact like the charlatans they licensed. They pretended to prohibit from healing those lacking the proper rank, but when money was handed over, "this man may heal and that man may sell medicines". Everyone profited, Pini concluded, but the sick. 119

This was certainly within the range of possibilities. From the point of view of licensees, at least, there was precious little difference between a protomedico's assiduity in collecting fees or merely lining his pockets. In 1639 the protomedico of Benevento, Pietro Piperno, was accused of excessive zeal in exercising his office by the city's barbers. They claimed that his earnestness simply masked his desire for the extra income it brought in. The city council agreed, deciding that the barbers should be inspected only once during the protomedico's three-year term. ${ }^{120}$ Furthermore, because the office of protomedico was often sold, office-holders were keen to make the most of their acquired position. In the Papal States the cost of the various provincial protomedicati varied according to the province's importance. ${ }^{121}$ When the viceroy of Sicily decreed that the office of consultor protomedico in Palermo would become a lifetime appointment (1743), it had already been sold for some time. The viceroy hoped that it would be sold to the most senior and experienced candidate, at a price not inferior to that paid in the past. ${ }^{122}$ In fact, Gerlando Fasulo paid 7,500 onze for the office in 1779; three years later the going rate was 8,260 (earnings amounted to 1,000 onze per annum). ${ }^{123}$

\footnotetext{
${ }^{118}$ The protomedico himself, Francesco Serrao, was opposed to any change. 'Relazione del Principe di Francavilla relativa alle visite di protomedici', A.S.N., Dip. Somm.: Protomedicato, series II, fascio 34, no. 16.

${ }^{119}$ Teseo Pini, 'Speculum cerretanorum', in Piero Camporesi (ed.), Il libro dei vagabondi, Turin, Einaudi, 1973, p. 66.

${ }^{120}$ Museo del Sannio, Benevento, Deliberazioni consiliari, 1631-40, fol. 380, cited in Alfredo Zazo, 'Spigolature sull'autore del De magicis affectibus: Pietro Piperno', Samnium, 1975, 48: 103-5, on p. 104. Piperno is best known for his work on magical afflictions, De magicis affectibus, published together with a treatise on the witches of Benevento in 1634. Cf. Michele Miele, 'Malattie magiche di origine diabolica e loro terapia secondo il medico beneventano Pietro Piperno (+1642)', Campania sacra, 1973, 4: 166-223.

121 Garofalo, op. cit., note 8 above, p. 15.

122 V. Parisi, Capitoli et ordinazioni della felice e fedelissima città di Palermo, Palermo, 1768, pp. 96-8, cited in Pitrè, op. cit., note 15 above, p. 164.

${ }^{123}$ Pitrè, op. cit., note 15 above, p. 261. Cf. Vittorio Sciuti Russi, 'Aspetti della venalità degli uffici in Sicilia (secoli XVII-XVIII)’, Rivista storica italiana, 1976, 88: 342-55, p. 348.
} 
Of course venality was typical of early modern office-holding and should not be regarded as synonymous with corruption. But protomedici had to recoup the costs of their office, vice-protomedici the costs of their tours of inspection, and the colleges the salaries they paid. Nobody admitted to corruption in any case. The guilty would either hide the fact by pleading innocence or falsifying entries on balance sheets or cite extenuating circumstances for their actions, removing any moral culpability. ${ }^{124}$ A Roman viceprotomedico in 1618, accused of not listing payments in the register and pocketing the money, simply admitted that he was unable to account for the irregularities. In any case, he added, he had been given no particular instructions by the college on his duties, not even the printed instructions, so "I therefore acted for myself". ${ }^{125}$ Moreover, abuses seem to have been a functional part of the system, each element of which sought to protect its individual position. This was akin to the strategy of bargaining and negotiation which was a normal feature of criminal cases, mentioned above (part II). Thus apothecaries in the Kingdom of Naples routinely claimed exemptions from the inspection duty (which in many cases were genuine, but sometimes not). Others shut their doors and fled upon the protomedico's approach, as we have seen. Still others petitioned that they had been charged too much. It is the nature of complaints by medical practitioners that they are always plausible, at least as far as the historian is concerned. What are we to make of the legions of midwives who had no idea that licences were required for their profession? Or those who petitioned for exemption, claiming to be, like a Neapolitan woman, "inabile e stupida" (unfit and slow)? ${ }^{126}$

\section{IV}

As offices so closely linked to the workings of the early modern state, most protomedicati met their end in the wake of Enlightenment reforms. Thus, in Milan, the reforms of the late eighteenth century sought to replace the autonomous jurisdictions of the colleges and the protofisicato with a single centralized and accountable bureaucracy, dependent on the state. A commission of experts was set up at the behest of the director of the medical faculty in 1766. Two years later, its report concluded that the protofisico's authority seemed to derive more from custom than from the authority of its 'Costituzioni'. Its licensing of surgeons into three classes was arbitrary and the various fees exacted owed more to the examiners' greed than the candidate's abilities. In 1774 a reformed Medical College with wide powers over health matters was established; the protofisicato was suppressed and the last protofisico retired. with an annual pension of 1,100 lire. ${ }^{127}$

The story in Siena is similar, where the protomedicato surrendered its powers to try offenders to the state courts in 1777, part of the physiocratic reforms of Grand-Duke

\footnotetext{
124 Jean-Claude Waquet, Corruption: ethics and power in Florence, 1600-1770, transl. L. McCall, Cambridge, Polity, 1991, pp. 107-14.

125 'Processo contro Rocco Montano V. Protomedico et altri', 1618, A.S.R., Università, b. 1, fols. 247-8v.

126 A.S.N., Dip. Somm.: Protomedicato, series II, fascio 35, "cautele".

${ }^{127}$ Malamani, op. cit., note 100 above, pp. 993-5 and 1001-2. At present, it is difficult to say how effective these reforms were. In France, the Société Royale de Médecine, established in 1776, "was relatively successful only in those areas where it had a clear royal mandate and did not infringe on the privileges of the local corporations", according to Ramsey, op. cit., note 9 above, p. 130. Both the Société Royale and the corporations were swept away by the Revolution, but real reform came only in 1803, with the jurys médicaux.
} 


\section{David Gentilcore}

Leopold. ${ }^{128}$ The office of protomedico, integral to the Medical College, survived until 1808, when the college itself fell victim to Napoleonic reforms. By this time, the Bolognese protomedicato had already ceased to exist, a victim of the aftermath of the 1796 French invasion.

Where the office survived, it was in a weakened form, deprived of the authority to try offenders. The protomedicato of Naples survived late-eighteenth-century calls for financial reform, as noted above. ${ }^{129}$ Under the reforms of Joachim Murat in the first decade of the nineteenth century, its fee-collecting activities merely passed from the ministry of finance to the ministry of the interior. Like its counterpart in Sicily, it came to an end with the unification of Italy. The Rome protomedicato outlived them all, surviving until 1870, when the city became part of a united Italy. By this time, however, its geographical extent had been reduced to the city itself and its activities confined to meetings of the Medical College at which university business was discussed.

This essay has sought to give an Italian connotation to words-protomedico and protomedicato-that are generally thought of as exclusively Spanish. In fact, the protomedicati in Italy differed markedly from their Spanish counterpart, and even from one another. We have divided them into three types: those which formed part of a medical college, those which were based on the Spanish model, and those which consisted of a single physician appointed by a town or city council. Nowhere did the Italian protomedicati have the influence and authority of the Spanish tribunal. To a much greater extent than in Spain they shared power with other magistracies, both of the state and the corporations. Relations between the protomedicati and these other bodies were generally harmonious, as exemplified by the tours of inspection which brought protomedico and proto-apothecary together. Yet the overlap of authority created questions of jurisdiction which could erupt into open disputes. And, like all office-holding in the ancien régime, the protomedicato was open to abuse and corruption. Finally, a survey of the surviving records suggests that there was relatively little change in their basic characteristics and the ways in which they functioned throughout the early modern period.

${ }^{128}$ Garosi, op. cit., note 33 above, p. 26.

129 By comparison, the Spanish protomedicato was suppressed in 1799 by royal decree, re-established and finally abolished in 1822. Granjel, op. cit., note 25 above, vol. 4, p. 92. 